\title{
Estudo dos Parâmetros Intervenientes no Deslizamento de Material Britado e/ou Rejeitos Produzidos em Pedreiras Urbanas
}

\author{
Izabelle Larissa Alves Lopes*, Mauro Menzori.
}

\section{Resumo}

A mudança na litosfera da Terra possibilitou o avanço da vida para os padrões que hoje conhecemos. Para progredir, no entanto, os seres humanos têm modificado rapidamente o Sistema Terrestre. O desenvolvimento humano tem muitas vezes caminhado com desastres ambientais e sociais irreparáveis, o que nos leva à prevenção e remediação de acidentes. Assim, esta pesquisa aborda uma das fontes de suprimento para o desenvolvimento humano que é a escavação e britagem, de material rochoso e lista quinze parâmetros relevantes e influentes no deslizamento de rejeitos em pedreiras urbanas, com foco no município de Limeira, São Paulo.

\section{Palavras-chave:}

Impacto ambiental, deslizamento, material britado depositado.

\section{Introdução}

O crescimento da população humana na Terra surgiu com a prática de plantio e de fixação a partir de construções simplificadas à elaboradas. Grande parte dessas construções foram e são feitas de materiais britados retirados na forma de lavra a partir da crosta terrestre, sendo que a melhor forma de beneficiamento é aquela que produz a menor quantidade de rejeitos ${ }^{1}$.

As lavras são normalmente de grande magnitude, e por isso seus acidentes e consequências devem ser sempre evitados. Este projeto visa apenas listar os principais parâmetros envolvidos no deslizamento de material britado, tendo o intuito de servir como referência para identificar e avaliar possíveis desastres em pedreiras urbanas.

O rejeito é o material não utilizado de imediato, aguardando futura destinação, depositado em áreas subterrâneas, a céu aberto, em edificações, ou em barragens com contenção ${ }^{2}$.

A região sudeste foi a mais afetada por deslizamentos $^{3}$, embora no Estado de São Paulo a incidência desse movimento seja menor, devido ao relevo de colinas, como na cidade de Limeira.

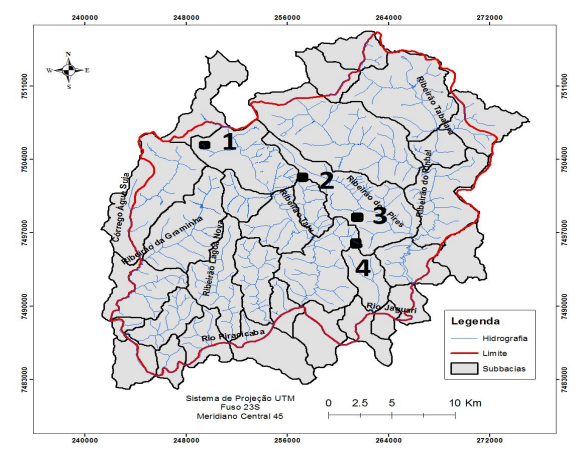

Figura 1. Pedreiras no Município de Limeira. Legenda: 1: Calcário Cruzeiro, 2: Pedreira Cavinatto, 3: Pedreira Limeirense, 4: Pedreira Basalto.

Fonte: Adaptada de autor desconhecido.

No município de Limeira foram localizadas quatro pedreiras: Pedreira Cavinatto, Pedreira Limeirense, Calcário Cruzeiro e Pedreira Basalto, que há décadas encontram-se em plena atividade sem a ocorrência de acidentes graves de deslizamento de material britado depositado.

\section{Resultados e Discussão}

São 15 os principais parâmetros encontrados na literatura que influenciam o deslizamento de material britado:

1) Geolocalização; 2) Condições Climáticas; 3) Análise das Amostras dos Materiais a serem escavados; 4) Parâmetros Geotécnicos do Material; 5)Tipos de Solo; 6) Profundidade da Rocha Mãe; 7) Legislação; 8) Formas de Extração e Beneficiamento; 9) Tempo de Deposição antes de ser retirado da lavra; 10) Movimentos de Massa; 11) Desmatamento; 12) Terraplanagem; 13) Modificação do sistema de drenagem natural; 14) Áreas de Risco: lixões e aterros; e 15) Topografia.

\section{Conclusões}

Por se tratar de um trabalho inicial sobre a situação das barragens no município de Limeira, a abordagem desse projeto está focada apenas no levantamento dos parâmetros que podem participar do deslizamento de material britado. Por esse motivo, neste projeto não existiu a coleta e a análise de dados. Contudo, a base conceitual sobre os parâmetros intervenientes no deslizamento de material rochoso servirá como referência para futuros estudos a serem realizados em um Trabalho de Conclusão de Curso e em um projeto de Mestrado desenvolvido futuramente.

${ }^{1}$ Lars K, Lund. Algumas considerações sobre o planejamento pré-operacional de pedreiras. Rio de Janeiro. 1976, 30p.

${ }^{2}$ Machado, William Gladstone de Freitas. Monitoramento de barragens de contenção de rejeitos de mineração. 2007. Dissertação (Mestrado em Engenharia Mineral)- USP, São Paulo, 2007. Acesso em 2019-06-30.

${ }^{3}$ Ministério da Integração Nacional. Anuário Brasileiro de Desastres Naturais. 2013.Disponívelem: $<$ http://biblioteca.incaper.es.gov.br/digital/bitstre am/item/386/1/Anuario-Brasileiro-de-Desastres-Naturais-2013.pdf. $>$. Acesso em: 02 jul.2019. 